\title{
Insulated Pressure Vessels for Vehicular Hydrogen Storage: Analysis and Performance Evaluation
}

S. M. Aceves, J. Martinez-Frias, O. Garcia-Villazana, and F. Espinosa-Loza

This article was submitted to 2001 American Society of Mechanical Engineers International Mechanical Engineering Congress and Exposition, New York, New York, November 11-16, 2001

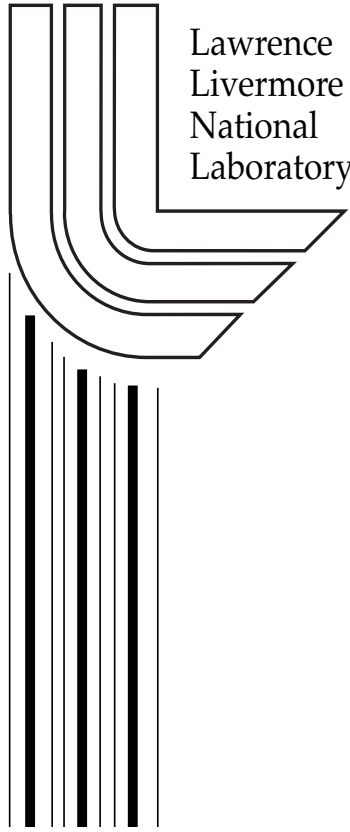

June 26, 2001 


\section{DISCLAIMER}

This document was prepared as an account of work sponsored by an agency of the United States Government. Neither the United States Government nor the University of California nor any of their employees, makes any warranty, express or implied, or assumes any legal liability or responsibility for the accuracy, completeness, or usefulness of any information, apparatus, product, or process disclosed, or represents that its use would not infringe privately owned rights. Reference herein to any specific commercial product, process, or service by trade name, trademark, manufacturer, or otherwise, does not necessarily constitute or imply its endorsement, recommendation, or favoring by the United States Government or the University of California. The views and opinions of authors expressed herein do not necessarily state or reflect those of the United States Government or the University of California, and shall not be used for advertising or product endorsement purposes.

This is a preprint of a paper intended for publication in a journal or proceedings. Since changes may be made before publication, this preprint is made available with the understanding that it will not be cited or reproduced without the permission of the author.

This report has been reproduced directly from the best available copy.

Available electronically at http://www.doc.gov/bridge

Available for a processing fee to U.S. Department of Energy

And its contractors in paper from

U.S. Department of Energy

Office of Scientific and Technical Information

P.O. Box 62

Oak Ridge, TN 37831-0062

Telephone: (865) 576-8401

Facsimile: (865) 576-5728

E-mail: reports@adonis.osti.gov

Available for the sale to the public from

U.S. Department of Commerce

National Technical Information Service

5285 Port Royal Road

Springfield, VA 22161

Telephone: (800) 553-6847

Facsimile: (703) 605-6900

E-mail: orders@ntis.fedworld.gov

Online ordering: http:/ / www.ntis.gov/ordering.htm

\section{OR}

Lawrence Livermore National Laboratory

Technical Information Department's Digital Library

http: / / www.llnl.gov/tid/Library.html 


\title{
INSULATED PRESSURE VESSELS FOR VEHICULAR HYDROGEN STORAGE: ANALYSIS AND PERFORMANCE EVALUATION
}

\author{
S. M. Aceves and J. Martinez-Frias \\ Lawrence Livermore National Laboratory \\ 7000 East Ave., L-644 \\ Livermore, CA 94551, USA \\ Phone: (925) 422-0864, Fax: (925) 423-7914 \\ Email: saceves@IInl.gov \\ O. Garcia-Villazana and F. Espinosa-Loza \\ FIMEE, Universidad de Guanajuato \\ Salamanca, Gto. Mexico
}

\begin{abstract}
Insulated pressure vessels are cryogenic-capable pressure vessels that can be fueled with liquid hydrogen $\left(\mathrm{LH}_{2}\right)$ or ambient-temperature compressed hydrogen $\left(\mathrm{CH}_{2}\right)$. Insulated pressure vessels offer the advantages of liquid hydrogen tanks (low weight and volume), with reduced disadvantages (fuel flexibility, lower energy requirement for hydrogen liquefaction and reduced evaporative losses). The work described here is directed at verifying that commercially available pressure vessels can be safely used to store liquid hydrogen. The use of commercially available pressure vessels significantly reduces the cost and complexity of the insulated pressure vessel development effort. This paper describes a series of tests that have been done with aluminum-lined, fiber-wrapped vessels to evaluate the damage caused by low temperature operation. All analysis and experiments to date indicate that no significant damage has resulted. Required future tests are described that will prove that no technical barriers exist to the safe use of aluminum-fiber vessels at cryogenic temperatures. Future activities also include a demonstration project in which the insulated pressure vessels will be installed and tested on two vehicles. A draft standard will also be generated for obtaining certification for insulated pressure vessels.
\end{abstract}

\section{Introduction}

Hydrogen-fueled vehicles present features that make them serious candidates as alternatives to today's petroleum-powered vehicles. Hydrogen vehicles can use the advanced technology of electric vehicles to improve environmental quality and energy security, while providing the range, performance, and utility of today's gasoline vehicles.

Probably the most significant hurdle for hydrogen vehicles is storing sufficient hydrogen on board. Hydrogen storage choices can determine the refueling time, cost, and infrastructure requirements, as well as indirectly influence energy efficiency, vehicle fuel economy, performance, and utility. There are at least three viable technologies for storing hydrogen fuel on cars. These are compressed hydrogen gas $\left(\mathrm{CH}_{2}\right)$, metal hydride adsorption, and cryogenic liquid hydrogen $\left(\mathrm{LH}_{2}\right)$. Each of these has significant disadvantages.

Storage of $5 \mathrm{~kg}$ of hydrogen (equivalent in terms of energy to 19 liters; 5 gallons of gasoline) is considered necessary for a generalpurpose vehicle, since it provides a $640 \mathrm{~km}$ (400 mile) range in a 34 $\mathrm{km} / \mathrm{liter}(80 \mathrm{mpg}$ ) hybrid vehicle or fuel cell vehicle. Storing this hydrogen as $\mathrm{CH}_{2}$ requires a volume so big that it is difficult to package in light-duty cars [1]. The external volume for a pressure vessel storing $5 \mathrm{~kg}$ of hydrogen at $24.8 \mathrm{MPa}$ (3600 psi) is 320 liters (85 gal). Hydrides are heavy (300 kg for $5 \mathrm{~kg}$ of hydrogen, [2]), 
resulting in a substantial reduction in vehicle fuel economy and performance.

Low-pressure $\mathrm{LH}_{2}$ storage is light and compact, and has received significant attention due to its advantages for packaging [3]. Significant recent developments have resulted in improved safety [4,5], and fueling infrastructure [6]. Disadvantages of low-pressure $\mathrm{LH}_{2}$ storage are the substantial amount of electricity required for liquefying the hydrogen [7]; the evaporation losses that may occur during fueling low-pressure $\mathrm{LH}_{2}$ tanks [8]; and the evaporative losses that occur during periods of inactivity, due to heat transfer from the environment.

An alternative is to store hydrogen in an insulated pressure vessel that has the capacity to operate at $\mathrm{LH}_{2}$ temperature $(20 \mathrm{~K})$, and at high pressure $(24.8 \mathrm{MPa} ; 3600 \mathrm{psi})$. This vessel has the flexibility of accepting $\mathrm{LH}_{2}$ or $\mathrm{CH}_{2}$ as a fuel. Filling the vessel with ambienttemperature $\mathrm{CH}_{2}$ reduces the amount of hydrogen stored (and therefore the vehicle range) to about a third of its value with $\mathrm{LH}_{2}$.

The fueling flexibility of the insulated pressure vessels results in significant advantages. Insulated pressure vessels have similar packaging characteristics as liquid hydrogen tanks (low weight and volume), with reduced energy consumption for liquefaction. Energy requirements for hydrogen liquefaction are lower than for liquid hydrogen tanks because a car with an insulated pressure vessel can use, but does not require, cryogenic hydrogen fuel. A hybrid or fuel cell vehicle with $34 \mathrm{~km} / 1$ ( $80 \mathrm{mpg})$ gasoline-equivalent fuel economy could be refueled with ambient-temperature $\mathrm{CH}_{2}$ at $24.8 \mathrm{MPa}(3600$ psi) and still achieve a $200 \mathrm{~km}$ range, suitable for the majority of trips. The additional energy, cost, and technological effort for cryogenic refueling need only be undertaken (and paid for) when the additional range is required for longer trips. With an insulated pressure vessel, vehicles can refuel most of the time with ambienttemperature hydrogen, using less energy, and most likely at lower ultimate cost than $\mathrm{LH}_{2}$, but with the capability of having 3 times the range of room-temperature storage systems. Use of compressed hydrogen in all trips under $200 \mathrm{~km}$ (which represent $85 \%$ of all the distance traveled in the USA, [9] reduces the total energy consumption by $16 \%$ over the energy consumed by a vehicle that is always filled with $\mathrm{LH}_{2}$.

Insulated pressure vessels also have much reduced evaporative losses compared to $\mathrm{LH}_{2}$ tanks. This has been demonstrated in a previous work [10], which presents a thorough analysis of evaporative losses in cryogenic pressure vessels based on the first law of thermodynamics. Figure 1 illustrates some of the main results. This figure shows hydrogen losses during vehicle operation. The figure assumes that two vehicles are fitted with cryogenic hydrogen storage tanks with the same capacity $(5 \mathrm{~kg})$. One vehicle has a lowpressure ( $0.5 \mathrm{MPa} ; 0$ psia maximum) conventional liquid hydrogen tank, and the other has an insulated pressure vessel. The vehicles are identical in every respect, except for the tanks. The vessels are filled to full capacity with liquid hydrogen, and then the vehicles are driven a fixed distance every day. When the fuel runs out, the amount of fuel burned by the engine and the amount of fuel lost to evaporation are calculated, and the results are shown in Figure 1. The figure shows total cumulative evaporative hydrogen losses out of a full tank as a function of the daily driving distance, for a high-efficiency vehicle (34 km/l or $80 \mathrm{mpg}$ gasoline equivalent fuel economy). As expected, evaporative losses increase as the daily driving distance is reduced, because less driving results in a longer time for hydrogen evaporation. The figure shows that a low-pressure $\mathrm{LH}_{2}$ tank loses hydrogen even when driven $100 \mathrm{~km}$ per day. Losses from a $\mathrm{LH}_{2}$ tank grow rapidly as the daily driving distance drops. A vehicle driven 50 $\mathrm{km}$ per day (the average for the USA, [10]) loses almost $1 \mathrm{~kg}(20 \%)$ of the fuel to evaporation. On the other hand, insulated pressure vessels lose hydrogen only for very short daily driving distances (less than $5 \mathrm{~km} /$ day). Most vehicles are driven considerably more than this distance, so that most vehicles equipped with an insulated pressure vessel would never lose any hydrogen to evaporation.

The low losses in insulated pressure vessels are the result of the flow work (work required to extract the hydrogen from the vessel, [11]). The hydrogen stored in the vessel does work as the hydrogen is being extracted, cooling down in the process. This effect is very significant for hydrogen, due to its low molecular weight.

From an engineering and economic perspective, insulated pressure vessels strike a versatile balance between the cost and bulk of ambient-temperature $\mathrm{CH}_{2}$ storage, and the energy efficiency, thermal insulation and evaporative losses of $\mathrm{LH}_{2}$ storage.

Considering all the potential benefits of insulated pressure vessels, it is important to determine what type of pressure vessel could be operated at both high pressure and cryogenic temperature. Of the available pressure vessel technologies commonly used for vehicular storage of natural gas [12], it appears that aluminum-lined, composite-wrapped vessels have the most desirable combination of properties for this application (low weight and affordable price). However, commercially available aluminum-composite pressure vessels are not designed for low temperature applications.

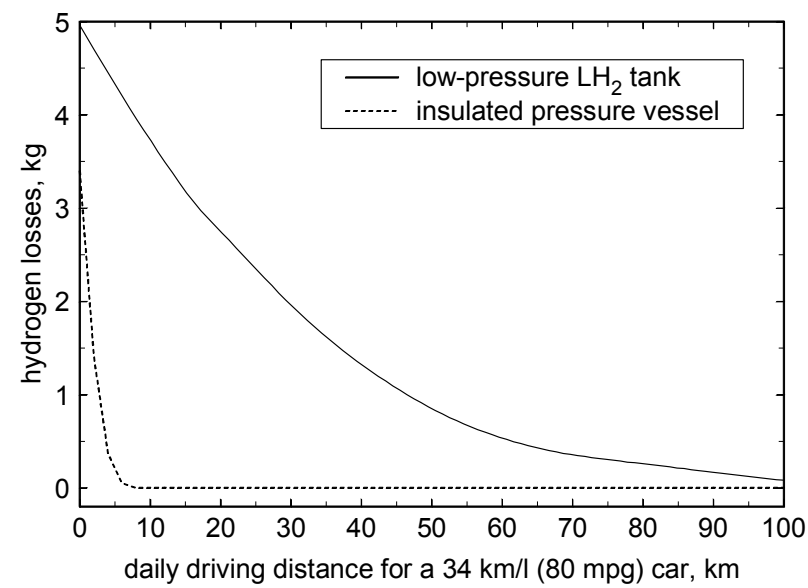

\footnotetext{
Figure 1. Cumulative hydrogen losses in $\mathrm{kg}$ as a function of daily driving distance, for vehicles with $17 \mathrm{~km} / \mathrm{liter}$ (40 $\mathrm{mpg}$ ); or $34 \mathrm{~km} / \mathrm{l}(80 \mathrm{mpg}$ ) fuel economy, for three cryogenic hydrogen storage vessels.
}

This paper describes work in progress directed at evaluating the possibility of using commercially available aluminum-fiber pressure vessels at cryogenic temperatures and high pressures, as would be required for vehicular hydrogen storage in insulated pressure vessels. The paper gives a description of previous and ongoing tests, followed by future tests. The purpose of these tests is to demonstrate that no technical barriers exist that prevent the use of aluminum-fiber pressure vessels at cryogenic temperatures. As a future task, we are 
planning to generate a draft for a certification standard which will be submitted to the relevant administrative bodies (DOT, ISO) for their consideration and approval. Another planned activity is a demonstration project in which insulated pressure vessels will be installed and tested on two vehicles.

\section{Completed Tests}

\section{Pressure and Temperature Cycling}

Pressure vessels have been cycled through 900 high-pressure cycles and 100 low-temperature cycles. The cycles are alternated, running 9 pressure cycles followed by a temperature cycle, and repeating this sequence 100 times. This test is expected to replicate what would happen if these vessels were used in a hydrogen-fueled car. Liquid nitrogen is used for low-temperature cycling and gaseous helium for high-pressure cycling. To accomplish the required testing, an experimental setup has been built inside a high-pressure cell. A schematic is shown in Figure 2. The valves shown in the schematic are controlled by computer, which allows the system to run with no supervision, resulting in fast cycling. An aramid-aluminum and a carbon fiber-aluminum pressure vessel have been cycled. The characteristics of these are listed in Table 1.

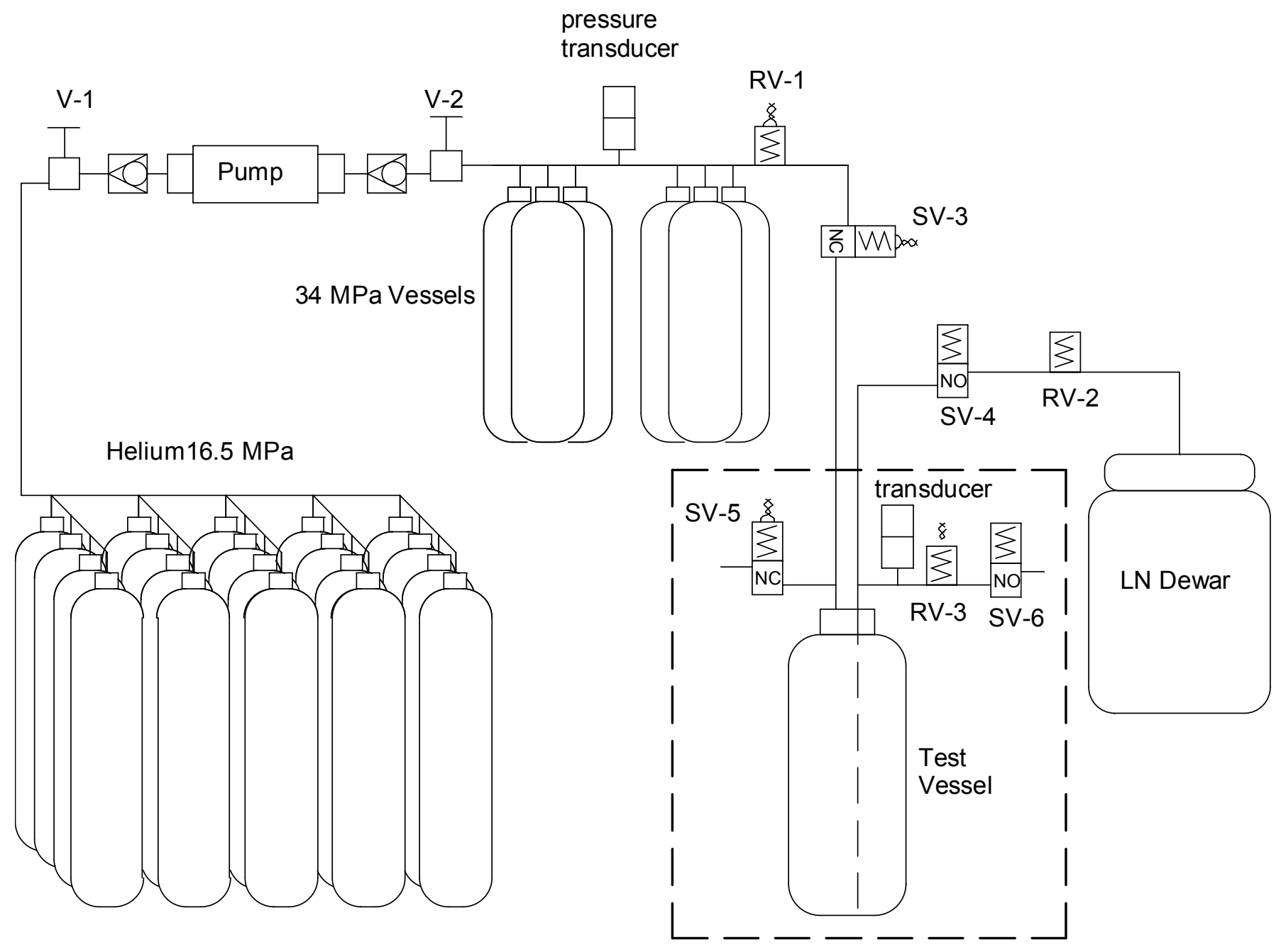

Figure 2. Schematic of the experimental setup for temperature and pressure cycling of pressure vessels.

Two cyclic tests have been completed, one on an aramidaluminum pressure vessel and other on a carbon fiber-aluminum pressure vessel. The vessels have not failed during the test, and they have not shown superficial evidence of damage under observation.
The carbon fiber-aluminum vessel was instrumented with strain gages in addition to the thermocouples and pressure sensor. Results from the strain gages will be used for validating the finite element analysis. 
Table 1. Characteristics of the Tested Hydrogen Vessels and Their Planned Insulation

$\begin{array}{ccc}\text { Aramid- } & \begin{array}{c}\text { Carbon } \\ \text { Aluminum }\end{array} & \begin{array}{c}\text { Fiber- } \\ \text { Aluminum }\end{array} \\ \text { Mass of hydrogen stored, kg } & 1.13 & 0.44 \\ \text { Vessel weight, kg } & 10 & 4.1 \\ \text { Internal volume, liters } & 17.6 & 6.8 \\ \text { Internal diameter, m } & 0.2 & 0.17 \\ \text { Internal surface area, m }{ }^{2} & 0.48 & 0.25 \\ \text { Design pressure, MPa (psi) } & 24.1(3500) & 31(4500) \\ \text { Performance factor }{ }^{1}, \mathrm{~m}\left(10^{6} \mathrm{in}\right) & 13000(0.5) & 13115(0.51) \\ \text { Safety factor } & 3.0 & 2.5\end{array}$

1 defined as burst pressure*volume/weight.

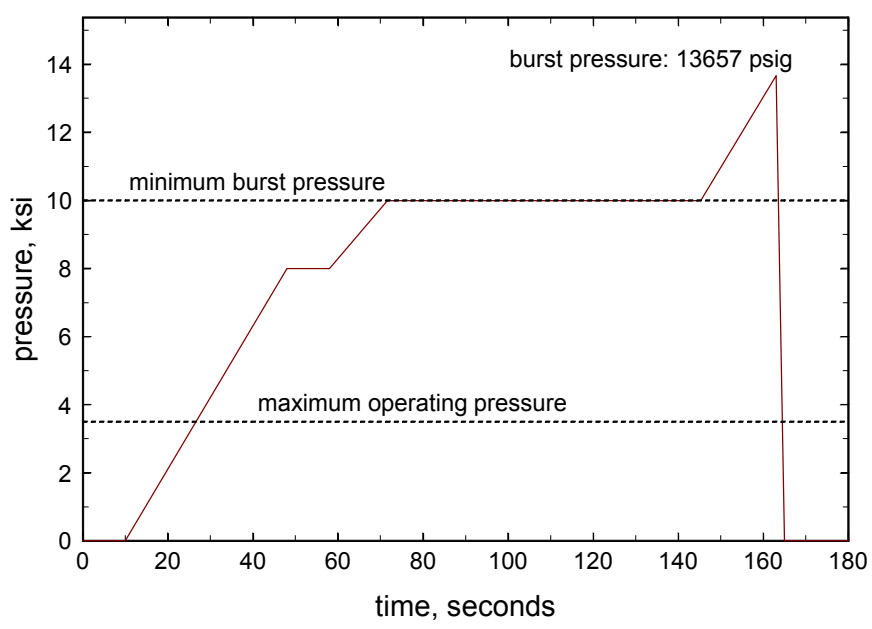

Figure 3. Pressure as a function of time during the burst test of the aluminum-lined, aramid-wrapped vessel. The burst pressure was 94.17 MPa (13657 psig).

\section{Burst Test}

The aramid-aluminum and the carbon fiber-aluminum pressure vessels were burst-tested after being cycled and ultrasound-tested. The burst test was conducted according to the Code of Federal Regulations-Department of Transportation standards for pressure vessel certification [13]. Figure 3 shows the variation of pressure as a function of time for the aramid-aluminum vessel. Failure occurred by hoop mid cylinder separation, which is the preferred mode of failure. The burst pressure was $94.2 \mathrm{MPa}(13.7 \mathrm{ksi})$, which is substantially higher than the minimum burst pressure of $72.4 \mathrm{MPa}(10.5 \mathrm{ksi})$. The very high value of the burst pressure compared to the minimum burst pressure may be due in part to work hardening that took place during the cold cycling of the vessel. The carbon fiber-aluminum also failed at a pressure higher than the minimum required.

\section{Finite Element Analysis}

Cyclic and burst testing of the pressure vessels has been complemented with a finite element analysis. The finite element analysis is done to determine whether low temperature operation can result in damage to the pressure vessel. Finite element analysis has been conducted with a commercial finite element package [14]. A mesh has been developed. This is an axisymmetric mesh with 1195 elements. Sensitivity of the results to mesh resolution was tested by building a second mesh with 4234 elements. Little difference was observed between the Von Mises stresses obtained with the two grids. Physical properties of fiber-epoxi laminae were obtained from available literature at ambient and cryogenic temperatures $[15,16]$. Lamina properties are then converted into properties of the composite matrix. This is done by using a computer program [17]. This program assumes that the matrix is a homogeneous, orthotropic material. The properties of the matrix are then used in the finite element thermal and stress analysis.

Finite element analysis of the pressure vessel includes the manufacture of the pressure vessel, starting from the curing process and continuing with the autofrettage cycle. The autofrettage is a process in which the vessel is subjected to a high internal pressure (45.5 Mpa, $6600 \mathrm{psi}$, in this case) to introduce a level of plastic deformation and pre-stress. After the autofrettage, the vessel is subjected to a series of low temperature and high-pressure cycles. These are identical to the sequence used for the cyclic test of the pressure vessel, consisting of a cryogenic cycle, down to liquid nitrogen temperature and followed by nine pressure cycles up to the design pressure.

Figure 4 shows the results of the analysis for plastic deformation in the aluminum at two points. These points are located at the center of the cylindrical part of the tank. The figure shows that the autofrettage cycle introduces a high level of plastic deformation. The first few cryogenic cycles also introduce some plastic deformation in the liner. However, successive cryogenic cycles introduce less and less plastic deformation, until the plastic deformation asymptotes to a value slightly higher than $4 \%$. Further cycles do not increase the level of plastic deformation, and therefore the pressure vessel is not expected to fail due to repeated cryogenic cycles. This is in agreement with the cryogenic cyclic tests, in which the vessels were subjected to 100 cryogenic cycles with no damage or failure.

\section{Insulation Design and Insulated Pressure Vessel Construction}

Insulated pressure vessels have been designed to operate with multilayer vacuum superinsulation (MLVSI). MLVSI has a good thermal performance only under a high vacuum, at a pressure lower than $0.01 \mathrm{~Pa}\left(7.5 \times 10^{-5} \mathrm{~mm} \mathrm{Hg}\right.$; [18]). Therefore, the use of MLVSI requires that an outer jacket be built around the vessel. Two designs for the insulation have been built: a first-generation design and a second-generation design. The first-generation vessel is a $1 / 5$-scale vessel that stores about $1 \mathrm{~kg}$ of liquid hydrogen, and it is shown in Figure 5. This design has been built for cyclic testing and for DOT certification tests. The insulation design includes access for instrumentation for pressure, temperature and level, as well as safety devices to avoid a catastrophic failure in case the hydrogen leaks into the vacuum space. Five pressure vessels have been built according to the first-generation pressure vessel design. These vessels have been tested or will be soon tested for compliance with DOT/ISO certification standards. 
The second-generation pressure vessel design is shown in Figure 6. This vessel can store about $6 \mathrm{~kg}$ of liquid hydrogen. This design includes a vapor shield to reduce evaporative losses in addition to the instrumentation and safety devices that exist in the first generation vessel. These vessels are currently being built. The second generation of pressure vessels will be used for DOT and SAE tests, and for incorporation into demonstration vehicles.

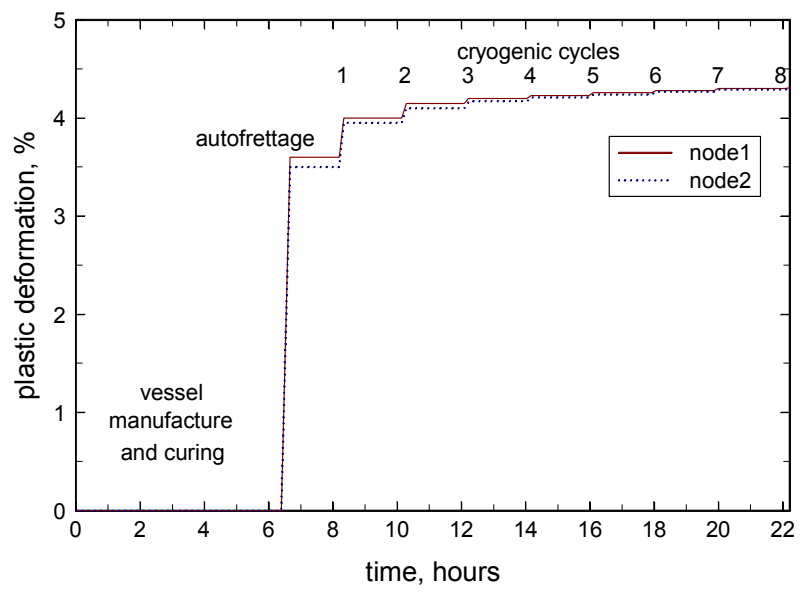

Figure 4. Plastic deformation obtained from the finite element analysis for two points in the aluminum liner. Nodes 1 and 2 are located at the center of the cylindrical part of the tank.

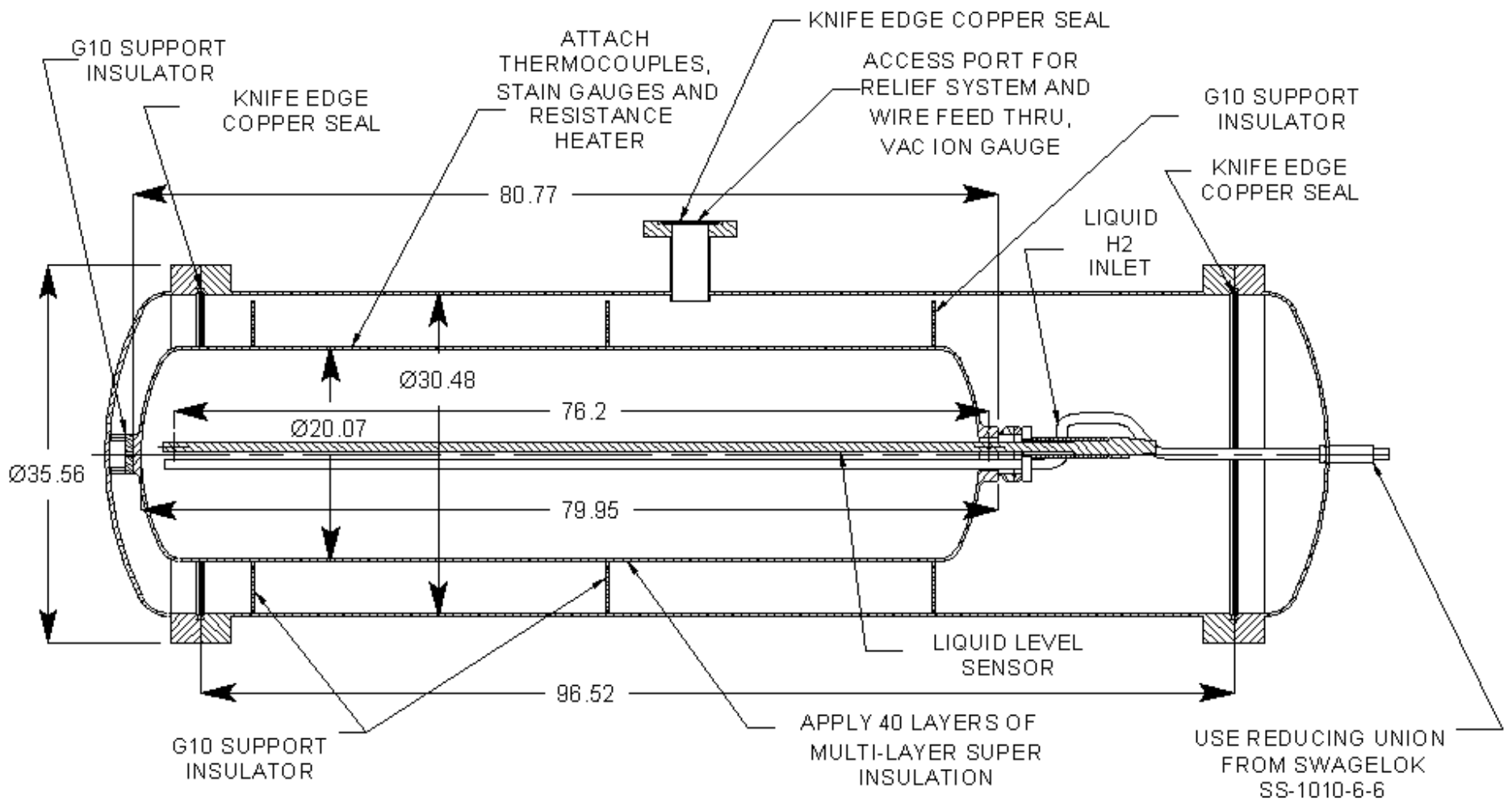

Figure 5. Insulation design for first-generation pressure vessel. The figure shows a vacuum space, for obtaining high thermal performance from the multilayer insulation, and instrumentation for pressure, temperature and level. Dimensions are given in cm. 


\section{Cyclic Testing of Insulated Pressure Vessels}

The insulated pressure vessels of the first generation (Figure 5) have been cycle tested. This is done to verify that the pressure vessel or the outer jacket does not develop leaks during repeated stresses that occur during cycling. One of these first-generation pressure vessels has been subjected to 1000 cycles, following the same procedure as previously used for the pressure vessels with no insulation (see "Pressure and Temperature Cycling" above). The remaining four first-generation pressure vessels have been subjected to a cold shock and pressure test before being subjected to DOT testing. The experimental setup for this test is the same as previously used for cyclic testing (Figure 2). The test procedure is as follows: The vessel is pressurized with compressed helium to 1.2 times the Maximum Allowable Working Pressure (MAWP). The pressure is held for a minimum of 30 minutes. Then, the pressure vessel is shock conditioned by cycling it 3 times to low temperature with liquid nitrogen. Finally, The vessel is leak tested with helium to 0.25 times the MAWP. Any leakage detected with a mass spectrometer leak detector is unacceptable. The same shock conditioning test procedure will be used for the second-generation, full-size pressure vessel before being tested according to the DOT and the SAE standards.

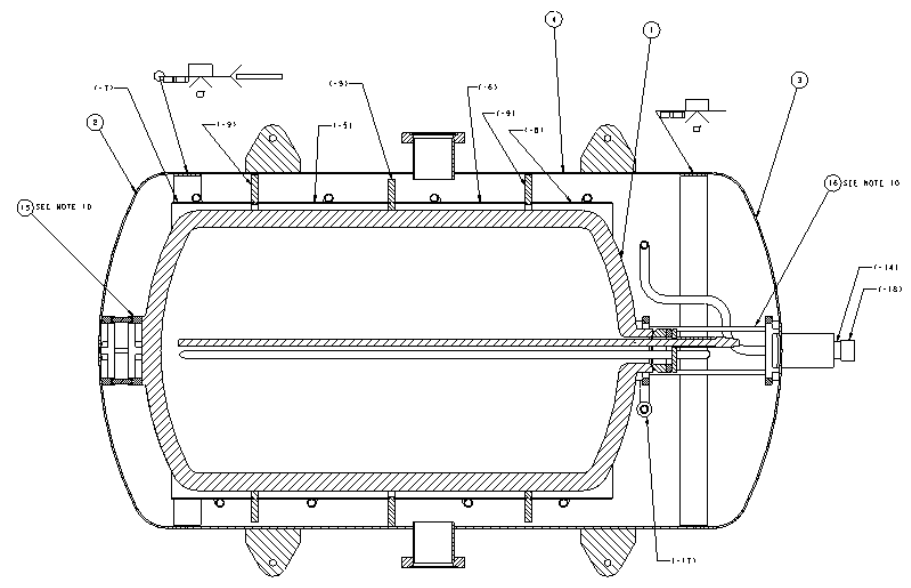

rigure 0 . Insuiation aesıgn tor secona-generation pressure vessel. The figure shows a vacuum space, for obtaining high thermal performance from the multilayer insulation, instrumentation for pressure, temperature and level, and a vapor shield for reducing hydrogen evaporative losses.

\section{Liquid and Gaseous Hydrogen Testing}

A first-generation insulated pressure vessel has been tested with liquid and gaseous hydrogen. The vessel was first shock-tested and leak-tested. The insulated pressure vessel was then transported to a remote facility for testing with liquid hydrogen. Testing involved filling the vessel with $\mathrm{LH}_{2}$ to study the insulation performance, the

performance of the sensors, and the problems involved with pumping the $\mathrm{LH}_{2}$ into the vessel. This test is expected to replicate what would happen to the vessel during fueling and operation in an $\mathrm{LH}_{2}$-fueled car. The test was conducted successfully. There was no damage to the vessel due to the low temperature operation, all the instrumentation operated properly at the low temperature, and there was no hydrogen ignition or explosions.

\section{DOT, ISO and SAE Certification Tests}

Along with the cryogenic cyclic tests and the finite element analysis, the insulated pressure vessels are being subjected to certification tests according to the standards set by the Department of Transportation (DOT), the International Standards Organization (ISO) and the Society of Automotive Engineers (SAE). A list of the tests that may be relevant to insulated pressure vessels has been generated, and so far five of the certification tests have been successfully completed with first-generation insulated pressure vessels (shown in Figure 5). The selected tests are listed next. The list also describes which tests have been completed and which are in progress.

- Cycling, ambient temperature. 10000 cycles from less than $10 \%$ of the service pressure to the service pressure, 10 cycles per minute maximum [13]. Each test cylinder must withstand the cycling pressurization test without any evidence of visually observable damage, distortion, or leakage. This test has been successfully completed.

- Cycling, environmental. 10 cycles per minute maximum. 1) 5000 cycles from zero to service pressure with tank at $60^{\circ} \mathrm{C}$ $\left(140^{\circ} \mathrm{F}\right)$ and air at ambient temperature and $95 \%$ humidity, 2) 5000 cycles from zero to service pressure with tank at $51.1^{\circ} \mathrm{C}\left(-60^{\circ} \mathrm{F}\right)$ and air at ambient temperature, 3$) 30$ cycles from zero to service pressure, ambient conditions 4) burst test the cycled vessel [13]. Each test cylinder must withstand the cycling pressurization test without any evidence of visually observable damage, distortion, or leakage. This test has been successfully completed.

- Cycling, Thermal. 10 cycles per minute maximum. 1) 10 000 cycles from zero to service pressure at ambient temperature, 2) 20 thermal cycles with tank temperature varying from $93.3^{\circ} \mathrm{C}\left(200^{\circ} \mathrm{F}\right)$ to $-51.1^{\circ} \mathrm{C}\left(-60^{\circ} \mathrm{F}\right)$ at service pressure, 3) burst test the cycled vessel [13]. Each test cylinder must withstand the cycling pressurization test without any evidence of visually observable damage, distortion, or leakage. This test has been successfully completed.

- Gunfire. Pressurize vessel with air or nitrogen to service pressure, and impact the vessel with a 0.30 caliber armorpiercing projectile with a speed of $853 \mathrm{~m} / \mathrm{s}(2800 \mathrm{ft} / \mathrm{s})$. The cylinder is positioned in such a way that the impact point is in the cylinder side wall at a $45^{\circ}$ angle with respect to the longitudinal axis of the cylinder. The distance from the firing location to the cylinder may not exceed 45.7 meters (150 feet) [13]. The cylinder shall not fail by fragmentation. This test has been successfully completed.

- Bonfire. Pressurize cylinder with air or nitrogen to service pressure. Set pressure relief devices to discharge at $83 \%$ of the cylinder test pressure. The cylinder shall be exposed to fire until the gas is fully vented. The temperature measured on the surface tank exposed to the fire has to be between 850 and $900^{\circ} \mathrm{C}[13,19]$. The venting of the gas must be predominantly through the pressure relief device.

- Drop Test from $3 \mathrm{~m}$ (10 ft). 1) The cylinder is dropped vertically onto the end, 2) the cylinder is dropped horizontally onto the side wall, 3 ) the cylinder is dropped onto a $3.8 \times 0.48 \mathrm{~cm}\left(1 \frac{1}{2} \times 3 / 16 \mathrm{inch}\right)$ piece of angle iron, 
4) after the drops, the vessel is cycled over 1000 pressure cycles from $10 \%$ of service pressure to the service pressure, at 10 cycles per minute $[13,19]$. The cylinder then has to be burst tested; the burst pressure of this vessel has to be at least $90 \%$ of the minimum burst pressure.

- Drop tests from $10 \mathrm{~m}$ and $3 \mathrm{~m}$. 1) Drop from $10 \mathrm{~m}$. The drop test subjects a full-size vehicle fuel tank to a free-fall impact onto an unyielding surface from a height of $10 \mathrm{~m}$. The fuel tank is released by firing one or more explosive cable cutters simultaneously. The fuel tank impacts the outer shell on the critical area as determined by the manufacturer. The fuel tank is filled with an equivalent full weight of liquid nitrogen saturated to at least $50 \%$ of the maximum allowable working pressure of the fuel tank. 2) Drop from $3 \mathrm{~m}$. The drop test subjects a full-size vehicle fuel tank to a free-fall impact onto an unyielding surface from a height of $3 \mathrm{~m}$. The fuel tank is released by firing one or more explosive cable cutters simultaneously. The fuel tank impacts the outer shell on the critical area as determined by the manufacturer. The fuel tank is filled with an equivalent full weight of liquid nitrogen saturated to at least $50 \%$ of the maximum allowable working pressure of the fuel tank [20]. There shall be no loss of product for a period of 1 hour after the drop other than relief valve operation and loss of vapor between the filler neck and the secondary relief valve in the case of a test involving the filler neck. Loss of vacuum, denting of the vessel, piping and piping protection, and damage to the support system are acceptable.

- $\quad$ Flame test. The tank should contain an equivalent full level of liquid nitrogen saturated at one half the maximum allowable working pressure (MAWP). The tank should be inverted and subjected to an external temperature of $538^{\circ} \mathrm{C}$ $\left(1000^{\circ} \mathrm{F}\right)$ for 20 minutes without the vessel reaching relief pressure [20].

Additional plans include the installation of insulated pressure vessels into demonstration hydrogen-powered vehicles. For this application, the NFPA [21,22], and CFR-DOT [13] standards will be reviewed to prepare the required tests to guarantee the safety of the operation. Future work will also focus on developing a testing procedure for achieving certification of insulated pressure vessels.

\section{Conclusions}

Insulated pressure vessels are being developed as an alternative technology for storage of hydrogen in light-duty vehicles. Insulated pressure vessels can be fueled with either liquid hydrogen or compressed hydrogen. This flexibility results in advantages compared to conventional hydrogen storage technologies. Insulated pressure vessels are lighter than hydrides, more compact than ambienttemperature pressure vessels, and require less energy for liquefaction and have less evaporative losses than liquid hydrogen tanks.

For reduced cost and complexity it is desirable to use commercially available aluminum-fiber pressure vessels for insulated pressure vessels. However, commercially available pressure vessels are not designed for operation at cryogenic temperature. A series of tests has been carried out to verify that commercially available pressure vessels can be operated at cryogenic temperature with no performance losses. All analysis and experiments to date indicate that no significant damage has resulted. Future activities also include a demonstration project in which the insulated pressure vessels will be installed and tested on two vehicles. A draft standard will also be generated for obtaining certification for insulated pressure vessels.

\section{Acknowledgments}

This project is funded by the DOE Hydrogen Program, Sig Gronich and Neil Rossmeisl, Program Managers. Work performed under the auspices of the U.S. Department of Energy by University of California Lawrence Livermore National Laboratory under Contract W-7405-ENG-48.

\section{References}

1. Pentastar Electronics, 1997, "Direct-Hydrogen-Fueled ProtonExchange-Membrane Fuel Cell System for Transportation Applications, Conceptual Design Report," Report DOE/CE/50390-9, prepared for U.S. Department of Energy, Office of Transportation Technologies, under contract DEAC02-94CE50390.

2. Michel, F., Fieseler, H., Meyer, G., and Theissen, F., 1996, "Onboard Equipment for Liquid Hydrogen Vehicles," Proceedings of the $11^{\text {th }}$ World Hydrogen Energy Conference, Stuttgart, Germany, pp. 1063-1077.

3. Braess, H.H., and Strobl, W., 1996, "Hydrogen as a Fuel for Road Transport of the Future: Possibilities and Prerequisites," Proceedings of the $11^{\text {th }}$ World Hydrogen Energy Conference, Stuttgart, Germany.

4. Pehr, K., 1996a, "Experimental Examinations on the Worst Case Behavior of $\mathrm{LH}_{2} / \mathrm{LNG}$ Tanks for Passenger Cars," Proceedings of the $11^{\text {th }}$ World Hydrogen Energy Conference, Stuttgart, Germany.

5. Pehr, K., 1996b, "Aspects of Safety and Acceptance of $\mathrm{LH}_{2}$ Tank Systems in Passenger Cars," International Journal of Hydrogen Energy, Vol. 21, pp. 387-395.

6. Hettinger, W. Michel, F., Ott, P., and Theissen, F., 1996, "Refueling Equipment for Liquid Hydrogen Vehicles," Proceedings of the $11^{\text {th }}$ World Hydrogen Energy Conference, Stuttgart, Germany, pp. 1135-1143.

7. Peschka, W., 1992, "Liquid Hydrogen, Fuel of the Future," Springer-Verlag, Vienna, Austria.

8. Wetzel, F.J., 1996, "Handling of Liquid Hydrogen at Filling Stations," Proceedings of the $11^{\text {th }}$ World Hydrogen Energy Conference, Stuttgart, Germany, pp. 1123-1134.

9. Klinger, D., Kuzmyak JR., 1984, "Personal Travel in the United States," Vol. 1, 1983-1984, Nationwide Personal Transportation Study, Report PB89-235378, prepared for the US Department of Transportation, Office of Highway Information Management, Washington, DC.

10. Aceves, S. M., Berry, G.D., 1998, "Thermodynamics of Insulated Pressure Vessels for Vehicular Hydrogen Storage," ASME Journal of Energy Resources Technology, June, Vol. 120, pp. 137142.

11. VanWylen, G.J., and Sonntag, R.E., 1978, "Fundamentals of Classical Thermodynamics," John Wiley and Sons, New York, NY. 
12. Institute of Gas Technology, 1996, "Compressed Natural Gas Storage Optimization for Natural Gas Vehicles," Gas Research Institute Report GRI-96/0364, Des Plaines, IL.

13. Code of Federal Regulations, Department of Transportation (CFR-DOT), 1996a, "Basic Requirements for Fully Wrapped Fiber Reinforced Aluminum Lined Cylinders," Title 49, CFR 107.105 Standard.

14. ANSYS, Inc., 1999, “ANSYS Version 5.6 Technical Handbook," Canonsburg, PA.

15. Reed, R.P., and Golda, M., 1994, "Cryogenic Properties of Unidirectional Composites," Cryogenics, Vol. 34, No. 11, pp. 909-928.

16. Morgan, R.J. and Allred, R.E., 1989, "Aramid fiber reinforcements," in "Reference Book for Composite Technology," Edited by Lee, S.M., pp. 143-166, Technomic Publishing, Lancaster, PA.

17. Hull, D., and Clyne, T.W., 1996, "An Introduction to Composite Materials," Cambrige University Press, Cambridge, Great Britain.
18. Kaganer, M.G., 1969, “Thermal Insulation in Cryogenic Engineering," Israel Program for Scientific Translation Ltd., Jerusalem, Israel.

19. International Standards Organization (ISO), 1999, "Gas Cylinders - High Pressure Cylinders for the on-Board Storage of Natural Gas as a Fuel for Automotive Vehicles," ISO Standard ISO/FDIS 11439: $\operatorname{ccyy}(\mathrm{E})$.

20. Society of Automotive Engineers (SAE), 1997, "Recommended Practices for LNG Powered Heavy-Duty Trucks," SAE.J2343.

21. National Fire Protection Association (NFPA), 1996, "NFPA 57: Liquefied Natural Gas (LNG) Vehicular Fuel System Code," Quincy, MA.

22. National Fire Protection Association (NFPA), 1998, "NFPA 52: Compressed Natural Gas (CNG) Vehicular Fuel System Code," Quincy, MA. 